\title{
The Presumption of Innocence: an Antidote for Sacrificial Venom? Patterns of Girard's 'Primitive' Sacred in Late Medieval and Early Modern Criminal Law
}

\author{
Rafael Van Damme
}

The presumption of innocence is regarded as the cornerstone of due process. It moulds the law of criminal procedure and as such rejoices almost universal acclaim. ${ }^{1}$ Appreciating the value of this principle in the contemporary world could be enhanced by examining legal systems whose procedural law is not, or not to the same extent, informed - in the Aristotelian sense - by the presumption of innocence.

The exotic universe of the criminal law in the ius commune tradition, from roughly the twelfth to eighteenth century, presents itself as a fine candidate, we think, to put things in perspective. On the one hand, learned jurists from this tradition were deeply concerned with due process. 'In dubio pro reo' or 'actori incumbit probatio' were widespread maxims of the medieval world, ${ }^{2}$ and the presumption of innocence is well established from the thirteenth century onwards. ${ }^{3}$ On the other hand, the ius commune testifies to an appalling furor puniendi $i^{4}$ discernable in a certain willingness to bypass procedural niceties. Procedure is the soul of the law, one could argue, wherein a society's sense of justice ${ }^{5}$ finds a ritualized expression. Lacché pictures it as an 'osservatorio privilegiato e barometro sensible del "grado di civiltà". ${ }^{6}$ As much as concepts of justice might be encrypted in the DNA of any law of proof, a legal system is not fully understood if one does not grasp the dialectical tension between the legal order and its suspension. Along-

1 Carl-Friedrich Stuckenberg, 'Who is Presumed Innocent of What by Whom?,' Criminal Law and Philosophy 8 (2014): 302; Kenneth Pennington, 'Innocent Until Proven Guilty: the Origins of a Legal Maxim,' The Jurist 63 (2003): 107.

2 Kenneth Pennington, The prince and the Law, 1200-1600: Sovereignty and Rights in the Western Legal Tradition (Berkeley: University of California Press, 1993), 156. For more information on the history of in dubio pro reo, see Peter Holtappels, Die Entwicklungsgeschichte des Grundsatzes 'in dubio pro reo' (Hamburg: Cram, de Gruyter \& Co., 1965).

3 Pennington, 'Innocent,' 114.

4 Matthias Schmoeckel, Humanität und Staatsraison: Die Abschaffung der Folter in Europa und die Entwicklung des gemeinen Strafprozeß- und Beweisrechts seit dem hohen Mittelalter (Köln: Böhlau, 2000), 251-4.

5 Pennington, 'Innocent,' 112.

6 Luigi Lacché, “'Ordo non servatus": Anomalie processuali, giustizia militare e "specialia” in antico regime,' Studi Storici 2 (1988): 362. 
side the ordo iuris stood (and maybe still stands) what Lacché has coined as the ordo non servatus. ${ }^{7}$ This is a regime to some extent unbound by legal prescripts, paradoxically attached to the law by its detachment from it. It entails extra-ordinary measures - heavily eroding the rights of the defense - devised to deal with exceptional crimes. ${ }^{8}$ The ius commune therefore seems to exhibit features of what is nowadays referred to as the state of exception, which Agamben depicted as 'a threshold, or zone of indifference', whose topological structure is a '[b]eing outside and yet belonging' to the law, or put differently: 'the legal form of what cannot have legal form'. In this 'anomic space' 'acts that do not have the value of law, acquire its force' ${ }^{9}$

In what follows we will explore some of the darkest corners of both the ius commune's penal order as of its anomic border zones. ${ }^{10}$ In an attempt to make sense of this domain, we will navigate by using as an intellectual compass the toolbox of concepts and distinctions generated by the French philosopher René Girard (1923-2015). His theory on (the disruption of) scapegoat mechanisms will serve, not as a quarry to mine for historical causality, but merely as hermeneutic frame of reference. Scapegoats are victims of collective aggression, accused and considered guilty of the most heinous crimes, but in fact virtually always innocent. They are mainly marginal figures, on the threshold of the inside and the outside of society, Fremdkörper in the social fabric, who somehow defy or resist being absorbed in the symbolic order. It would come as no surprise when a connection could be established between these exceptional figures and the state of exception which shimmers through in the ordo non servatus. The legal historian Pennington observes: 'It has been true in the past and it remains true today that procedural rules are broken and rights violated most often when judges have faced crimes that strike society's most sensitive nerves. The cases in which I have found that the presumption of innocence is discussed again and again are those that dealt with marginal groups, especially heretics, witches and Jews'. ${ }^{11}$ We therefore presume an inverse correlation between the extent to which the presumption of innocence informs criminal procedure and the extent to which criminal law might become the vessel of scapegoat dynamics. Girard develops a speculative philosophy of history, claiming that we have partially but increasingly outgrown scapegoat dynamics by becoming ever more aware of and reluctant towards our tendency to abreact aggression and social tensions by exerting collective violence on scapegoats. ${ }^{12}$ One could wonder what better domain there is to test this hypothe-

7 Proposed translation: 'the order/procedure which has not been observed', in other words, the violation of legal order.

8 Lacché, 'Ordo,' passim.

9 Giorgio Agamben, State of Exception (Chicago: The University of Chicago Press, 2005), 1, 23, 35, 38-9.

10 Some scholars will most likely deem Agamben's notion 'anomie' to be untenable for the Middle Ages and would prefer to speak of a legal rather than an anomic space of exception. For our argumentation to use this Agambenian notion, see note 125.

11 Pennington, 'Innocent,' 117.

12 René Girard, Ik zie Satan vallen als bliksem (Kampen: Agora/Pelckmans, 2000), 154-67. 
sis than the history of criminal law. ${ }^{13}$ We will therefore endeavour to establish some 'family resemblances', to use Wittgenstein's phrasing, between scapegoat dynamics and criminal law. The assumption from which our line of thought springs is that there are clues to be found in the history of criminal law, especially in dealing with severe crime, which could be interpreted as indications of an historical development towards a lower grade of participation of the law in scapegoat dynamics. This paper aims to attribute at least a fraction of corroboration of this claim by showing how the contemporary understanding of the presumption of innocence is conceptually opposed to scapegoat dynamics in criminal law. Our legal maxim might therefore have played a pivotal role in the possible disruption of legally codified scapegoat dynamics. We hope to substantiate our view by showing that some legal concepts found in the ius commune's penal system (mala fama, torture, atrocitas/enormitas, notorium, poena extraordinaria, absolutio ab instantia) are (1) compatible with or at least affiliated to scapegoat dynamics and are (2) more or less flagrant breaches of our contemporary conception of due process as informed by the presumption of innocence. Their disappearance from the legal scene might now appear in the light of partially disrupted scapegoat dynamics.

\section{Girard's theory of scapegoat mechanisms and ritual sacrifice}

Violence is contagious, says Girard. It can spread like an epidemic, dissolving social structure. In a small tribal culture, one murder can instigate a cycle of vendetta, eventually resulting in a bellum omnium contra omnes. Girard claims this opposition of all against all can only be overcome by a scapegoat mechanism: an opposition of all against one in a spontaneous and uncontrolled outburst of collective violence directed at a generally innocent victim. Social turmoil is appeased by deviating the violence of all on one subject whose death is unlikely to be avenged as long as everyone is utterly convinced of his alleged guilt. Ordinary violence results in more violence, as it is violently responded to. The violence of all against one, however, is of a special kind, since it prevents further escalation. It is therefore considered to be sacred (or later in history, legitimate). The scapegoat is a marginal figure, as we said, who was often continuously despised, suspect, and ill-reputed, as coping with alterity is not exactly humankind's greatest gift. In the paroxysm of rampant violence spreading through society, he might be accused of crimes thought to have caused the crisis. These crimes are always atrocious, attacking the core differences upon which the symbolic order is built. They include transgressing sacred taboos, attacks on hierarchy, and illicit sexual acts. In each case, an essential symbolic dichotomy is being transgressed (sacred/profane, higher/lower, sexual/asexual). As the scapegoat was the pivotal figure in society's rapid transformation from chaos to peace, and since his life was deemed

13 At least from the eleventh to twelfth century onwards, when crime was no longer considered to be a private, but increasingly a public concern, and punishment consequently came to represent a collective response to an infraction of order. See Lotte Kéry, Gottesfurcht und irdische Strafe: Der Beitrag des mittelalterlichen Kirchenrechts zur Entstehung des öffentlichen Strafrechts (Köln: Böhlau Verlag, 2006), passim. 
a source of death and his death was a source of life, supernatural powers were ascribed to him. Collective violence had led to a process of sacralization. Girard writes: 'C'est la violence qui constitue le cœur véritable du sacré'. ${ }^{14}$

In the spontaneous and uncontrolled collective violence of the scapegoat mechanism - the life vessel of 'primitive'15 society on the verge of collapse - Girard sees the origin of both taboo and ritual. In other words: scapegoat mechanisms are the hidden foundation of social order. Taboo prohibits all acts which were deemed to be capable of catapulting society back into a bellum omnium contra omnes. If taboo might be considered as the archaic origin of material law, scapegoating appears as Benjamin's law-positing violence (rechtsetzende Gewalt) - one of two possible manifestations of what he calls 'mythic violence. ${ }^{16}$ Ritual on the other hand reenacted the scapegoat mechanism, in a meticulously controlled and formalized way, in order to reproduce its beneficial effect. Therefore, it mostly ends in bloodshed (sacrifice) and could be performed whenever social unrest needed to be appeased and/or the order needed to be reinvigorated. ${ }^{17}$ The sacrificial system therefore corresponds to the other manifestation of Benjamin's mythic violence: law-preserving violence (rechtserhaltende Gewalt). ${ }^{18}$

Girard thinks the scapegoat mechanism was unveiled by Christianity, since the gospel portrays Christ as a scapegoat, an innocent victim who fell prey to collective aggression. Since the scapegoat mechanism only functions as long as those involved have not identified it as such and, unaware of what they are doing, vehemently express how justified their anger is, the gospel has, in unveiling the injustice of what has been moulding culture 'depuis la fondation du monde', 19 delivered a fatal blow to the effectiveness of the mechanism. 'L'essentiel de la révélation [...], c'est la crise de toute représentation persécutrice qu'elle provoque'. ${ }^{20}$

\section{The consanguinity of sacrifice and criminal law?}

Before our Girardian ship can leave port and head for the turbulent seas of criminal law, it must be argued why the vessel is apt to sail these waters in the first place. Our travels will only bear fruit if we can indicate a plausible interrelatedness of legal order and scapegoat dynamics. In many ways, legal order might be conceived as remotely and indirectly marked by the blueprint of the scapegoat

14 René Girard, La violence et le sacré (Millau: Pluriel, 2010), 51 and passim; René Girard, Le bouc émissaire (Paris: Grasset, 1985), passim.

15 See note 44 on the reasons why we use this obsolete concept.

16 Walter Benjamin, 'Zur Kritik der Gewalt,' in Walter Benjamin, Gesammelte Schriften, ed. R. Tiedemann and H. Schweppenhäuser, Vol. 2, 1st ed. (Frankfurt am Main: Suhrkamp, 1999), see <https://musiclanguagethought.files.wordpress.com/2011/02/benjamin-zur-kritik-der-gewalt. pdf> (accessed 28 February 2015), 5.

17 Girard, La violence, passim.

18 Benjamin, 'Zur Kritik,' 5.

19 René Girard, Des choses cachées depuis la fondation du monde: Recherches avec Jean-Michel Oughourlian et Guy Lefort (Paris: Grasset, 1978).

20 Girard, Le bouc, 166. 
mechanism. The latter thrives on mob psychology, singling out an almost randomly selected victim by constructing an imaginary causal link between an (often illusionary) transgression he would have committed and all-too-real social turmoil as its alleged detrimental consequences. What is in fact an aleatory process ${ }^{21}$ is being covered up by a presumption of guilt so massive it amounts to a 'verdict'. If abstraction could be made of the almost impenetrable jungle of concepts and doctrines law has by now become, jurists might agree that a great deal of it still revolves around an (in theory) rationalized, legalized, truth-seeking, and just-ified version - or should we say: inversion? - of the very same triangle we acquainted ourselves with in the scapegoat mechanism: transgression, damage, and causality. ${ }^{22}$ Penal law in specific hopes to be everything but aleatoric and triggerhappy when it strikes. Therefore, it anchors punishment in the principle of guilt and procedure in the presumption of innocence. Scapegoating and criminal law, however, bear structural resemblances: they solve social tensions or violence by an exclusionary opposition of all against one in an act of collective(ly sanctioned) violence preventing violence from spreading further. But let us not jump from the scapegoat mechanism to criminal law, without elaborating on the bridge that connects them, according to Girard, namely the sacrificial system. ${ }^{23}$

One of the major contrasts he highlights between the archaic and the modern world is the way conflicts are resolved and/or prevented. Whereas the former was dependent on sacrifice, the latter has developed legal institutions. ${ }^{24}$ Both systems stand united in terms of ends, namely overcoming the reciprocity of vengeance, but are so fundamentally distinctive in terms of means that their possible consanguinity is all too easily overlooked. The crucial difference is that sacrifice is indifferent towards the question of guilt, this being the exclusive fetish of the law. Whereas criminal law targets the culprit, sacrifice prevents violence to bounce back on the violator, but provides an outlet valve by deflecting it on surrogate victims (e.g., a foreigner, a marginal figure, an outcast, a prisoner of war, an animal,...). These were so poorly integrated no one would avenge them, so their sacrificial immolation soothed the blood rush without prompting any further violent response. ${ }^{25}$ Although victim selection was in principle random (some crea-

21 For a qualification of this process, see note 26.

22 For the sake of clarity a causal link establishes the damage as a consequence of the transgression.

23 The sacrificial system is by some scholars identified as the model according to which one can understand the genesis of criminal law's 'crown jewel': capital punishment. Cf. Karl von Amira, Germanische Todesstrafen: Untersuchungen zur Rechts- und Religionsgeschichte, Abhandlungen der Bayerischen Akademie für Wissenschaften, Phil.-Hist. Klasse, 31, 3 (München: Verlag der Bayerische Akademie für Wissenschaften, 1922); Karl Bruno Leder, Todesstrafe: Ursprung, Geschichte, Opfer (München: Meyter, 1980), 63-5; Wolfgang Sofsky, Traktat über die Gewalt (Frankfurt am Main: S. Fischer Verlag, 1996), 124; for a Girardian view, see Wolfgang Palaver, 'Sakrales Königtum, Todesstrafe, Krieg: Der Ursprung politischer Institutionen aus der Sicht der mimetischen Theorie René Girards,' Revista Portugesa de Filosofia 58(2) (2002): 367-72; for Girard's own account: see Girard, La violence, 445-8.

24 Girard, La violence, 9-46.

25 Some rituals elucidate the preoccupation of vengeance very clearly when for instance even the 'family clan' of the sheep one is about to slaughter is being requested not to avenge the sacrifice. Cf. Girard, La violence, 26. 
ture has to take the hit), in practice, it generally targeted society's weakest links. ${ }^{26}$ Why, one might wonder, did 'primitive' societies, deeply preoccupied with the danger springing from a non-avenged victim, prevent vengeance being carried out on perpetrators? Because there was no state authority that could prevent vendetta from spiraling out of control. Sacrifice is therefore about breaking the reciprocity of violence by deflection, in the absence of state monopoly on violence functioning as an impregnable and untouchable bulwark of public vengeance able to prevent or stop blood feuds. ${ }^{27}$ 'Si le primitif paraît se détourner du coupable [...] c'est parce qu'il redoute de nourrir la vengeance', says Girard. '[C]'est en tant que coupable [...] que le coupable est epargné', because '[f]aire violence au violent, c'est se laisser contaminer par sa violence'. ${ }^{28}$ The judicial system, on the other hand, remains faithful in a strict sense to the principle of vengeance, which it has

26 The fact that victims so often belong to specific groups does not impede that within this limited scope an aleatoric selection process is at hand. A small excursus on the ordeal can serve as an illustration of what we mean by this: in trial by combat, the potential victims are narrowed down to a pair, but whom it will be is largely left to chance; in a trial by fire (the accused holds a hot iron bar and if his wounds are found to be 'clean' after three days, God has testified to his innocence (Robert Bartlett, Trial, by Fire and Water: The Medieval Judicial Ordeal (Oxford: Clarendon Press, 1986), 1), there is only one possible victim, but the outcome is nevertheless aleatoric.

27 It is worth noting that, according to Whitman, the earliest 'state-like authorities', which produced archaic bodies of law like the 'codex' Hammurabi in Mesopotamia (eighteenth century BC) or the Twelve Tables in Rome (fifth century BC), were not striving for a monopoly on violence, not even engaging 'in suppressing, or [...] supervising, vengeance-violence in any systematic way', but rather aimed 'to bring ritual and social order to societ[y]'. Not all of the abundant archaic talionic provisions of mutilation, of which the biblical 'an eye for an eye, a tooth for a tooth' (Ex. 21:24, Lev. 24:20, Deut. 19:21) has become proverbial, have to do with vengeance, he says. To interpret them correctly, we must be attentive to the 'mysterious winds of archaic religion moving through our sources' and 'be willing to cast an eye upon sacrificial practices.' By contrast, with regard to the rise of the European states in the Central Middle Ages, the 'monopoly of violence' model is by Whitman deemed to be relevant (James Q. Whitman, 'At the Origins of Law and the State: Supervision of Violence, Mutilation of Bodies, or Setting of Prices?,' Chicago-Kent Law Review, 71(41) (1995): 72, 76-7, 79, n.160). We think Whitman's findings are not incompatible with Girard's philosophy. First of all, we learn that the earliest bodies of law are deeply embedded in archaic religion's - de facto - sacrificial mindset. Second, the observation that talionic provisions have to do both with vengeance and sacrificial rites at least suggests some connection between the two, although Whitman refrains from putting the problem of vengeance at the heart of sacrifice, which he merely claims (on p. 83) to be profoundly difficult to interpret. Whitman's position is understandable, even from a Girardian perspective, since for Girard sacrifice was performed whenever social unrest needed to be appeased or just as well at fixed points in time to reinvigorate social order. Its scope is therefore far from restricted to the field which we would anachronistically label as criminal law. Besides, Girard's utterances on the link between sacrifice and vengeance are subtler than we have presented them. He says for instance that the connection between sacrifice and a preceding irregular act of bloodshed is never apparent but adds this is why the relationship between social violence and sacrifice continues to elude us (Girard, La violence, 43). Thirdly, using the Girardian hermeneutic toolbox, we can shed light on Whitman's assertion that the earliest state-like authorities did not even seek to control vengeance by referring exactly to the sacrificial context in which they emerged. There was still sacrifice to deflect vengeance and therefore a monopoly on violence might not have been a priority. As the embryonic medieval states no longer had this advantage, establishing the monopoly on violence appears as the most viable way to contain blood feuds. 
rationalized by reciprocation of violence exclusively on the violator. ${ }^{29}$ Its potential to end/prevent vengeance depends on the strength of state power: only in as far as the state has become a transcendent entity whose blows are immune for contestations and counterblows, can it exert 'une violence vraiment décisive et terminale, [...] une violence qui mettrait fin [...] à la violence'. ${ }^{30}$ Girard thinks that vengeance, sacrifice, and criminal punishment are nevertheless identical on a deeper level. His argument is that if sacrifice goes wrong, ${ }^{31}$ or if authority crumbles to such an extent that state justice is no longer accepted as the final word, institutionalized violence will spark violence in exactly the same way as vengeance would. $^{32}$ The sacred aura that sacrifice always enjoyed as violence that purifies society by relieving its tensions was passed on to the legal system for exactly the same reason. Both sacrifice and justice refer to a theology legitimating their acts, differentiating sacred - or pure - and legitimate violence from its impure and illegal counterparts. Although the theology behind justice might have disappeared in our days, its transcendence remains - meaning that the label 'legitimate' prevents its acts from being contested and reciprocated. ${ }^{33}$ If one were to treat sacrifice and the judicial system as mutually exclusive Weberian Idealtypen, then the hallmark of sacrifice is aleatory victim selection, hereby wilfully neglecting the guilty party, while criminal law theoretically rejects randomness by focusing exclusively on the culprit whose guilt is to be established by the law of proof. Although these ideal types might be recognizable at the extremes of the chronological spectrum, in the course of history, they seem to have merged in various hybrid forms (e.g., surrogate punishment ${ }^{34}$ or simply coexisted alongside each other (e.g., antiquity). ${ }^{35}$ One should not hastily conclude that whenever legal persecution is guided by nulla poena, nullum crimen sine culpa, the realm of sacrifice and scapegoating has been definitively surpassed. The real issue is of course to what extent first and foremost the law of proof has been purified from all aleatory tendencies in defining and establishing guilt. That these were not shaken off in one swift movement is apparent 'dans bien des formes intermédiaires entre le

29 Girard, La violence, 39.

30 Girard, La violence, 41, quote on 45.

31 Girard, La violence, 64-6.

32 Girard, La violence, 42. If the hypothesis that public executions are in some way tributary to the sacrificial system would be accepted, then poorly performed executions might count as sacrifices that went wrong. Spierenburg (who, it must be said, strongly opposes this line of interpretation) notes for instance: 'Examples of assaults by the populace on clumsy hangmen are abundant.' He also stresses that executions are often connected to riots and outbreaks of violence. Cf. Pieter Spierenburg, The Spectacle of Suffering: Executions and the Evolution of Repression: From a Preindustrial Metropolis to the European Experience (Cambridge: Cambridge University Press, 1984), quote on 14, 100-9.

33 Girard, La violence, 41-2.

34 Harald Maihold, Strafe für fremde Schuld: Die Systematisierung des Strafbegriffs in der Spanischen Spätscholastik und Naturrechtslehre (Köln-Weimar-Wien: Böhlau Verlag, 2005). For our sacrificial interpretation of Maihold's work, see Rafael Van Damme, 'How the Principle of Guilt Purified Criminal Law from Sacrificial Remnants: A Girardian interpretation,' LOEWE Research Focus 'Extrajudicial and Judicial Conflict Resolution' (working paper) 6 (2014). See <http://publikationen. ub.uni-frankfurt.de/frontdoor/index/index/docId/32901> (accessed 24 February 2015).

See also note 27. 
religieux et le judiciaire proprement dit, dans l'ordalie notamment', says Girard. ${ }^{36}$ Whether the ius commune's legal order, that was partly built on the ruins of the ordeal (cf. infra), was sufficiently freed from sacrificial inclinations, is to be judged, we think, by its law of proof (how the obtainment, the standard, and the burden of proof is conceived, whether suspicion is clearly fenced off from guilt, if the accused is presumed innocent until proven guilty and to what extent, in general, the principles of due process are being upheld). Our understanding of the history of criminal law can benefit from a conceptual differentiation between sacrifice and law to uncover patterns and cast shades, but we ought to remain sensible not only of their possible factual historic amalgamation but also of their profound consanguinity. Criminal law might be a mutation of sacrifice but still shares the bulk of its DNA, so to speak. This is patent in the mere fact that both conceptual pairs, 'taboo/sacrifice' and 'law/punishment', generate social order and stability by offering the group an individual to take the hit when order was infringed upon or is felt to be under threat. If one would define law very broadly and generally as an 'institutionalized ordering of human conduct in society', ${ }^{37}$ then 'primitive' societies have come close to something resembling legal order. ${ }^{38}$ Within this shared framework, sacrifice and law, considered in their pure ideal typical form, can be seen, however, to operate under a different logic (aleatory vs. guilt-oriented) when it comes to determining who will go under the knife.

36 Girard, La violence, 448 (Girard's italics); see also on randomness: James Q. Whitman, The Origins of Reasonable Doubt: Theological Roots of the Criminal Trial (New Haven: Yale University Press, 2008), 15-6. See also note 26.

37 Marck Van Hoecke and Boudewijn Boeckaert, Inleiding tot het recht (Leuven/Den Haag: Studie Juri, Acco, 2014), 37 (my translation).

38 For an overview on the question how law could be defined, see Uwe Wesel, Frühformen des Rechts in vorstaatlichen Gesellschaften: Umrisse einer Frühgeschichte des Rechts bei Sammlern und Jägern und akephalen Ackerbauern und Hirten (Frankfurt am Main: Suhrkamp, 1985), 52-68. 
Since sacrifice was a highly formalized ritual ending in bloodshed, it might be a distant ancestor of an equally formalized law of criminal procedure ${ }^{39}$ culminating

39 To establish a link between procedural law and rituals, let us begin by mentioning that the latter are said to be 'behavior that is socially standardized [..,] defined by formalism, traditionalism, disciplined invariance, rule governance [and] sacral symbolism', just like the former (Kaius Tuori, Lawyers and Savages: Ancient History and Legal Realism in the Making of Legal Anthropology (New York: Routledge, 2015), 177). The best Girardian quote we have on offer to corroborate our claim is: 'Le rite ne reste vivant que s'il canalise dans une direction déterminée des conflits politiques et sociaux réels. Il ne reste rite, d'autre part, que s'il maintient l'expression conflictuelle dans des formes rigoureusement déterminées' (Girard, La violence, 165). Despite the obvious disparity with regard to the lack of institutionalized differentiation (e.g., the mentioning of political conflicts), the affinity with criminal procedure is obvious. But there is more. Scapegoat mechanisms entail a crisis: strife, struggle, and violence abound before the group turns towards its victim. Girard sees mimetic undifferentiation between antagonists as the primal core of all types of violent behaviour. It is because every argument, insult, or blow is reciprocated in kind that opponents become each other's doubles, so to speak. Plenty of rituals therefore contain mock battles or even ritual disputes on whom will be sacrificed have been found. 'Il s'agit toujours, pour chacun, de proférer le dernier mot [...] en réduisant au silence l'antagoniste' (Girard, La violence, 186). Hence, conceptually, the gap between ritual and the realm of litigation appears to be bridgeable, whether one imagines trial by combat or a more civilized clash between intendedly definitive legal arguments of both parties. Moreover, the accusatorial procedure (cf. infra) portrays a staggering degree of the typically ritualistic 'dissolving of distinctions' (Girard, La Violence, 166-7): in the twelfth and thirteenth century, "les deux parties sont maintenues sur un strict plan d'égalité: [...] si l'accusé était détenu, l'accusateur devait lui aussi "tenir prison"' (JeanMarie Carbasse, Histoire du droit pénal et de la justice criminelle (Paris: Presses Universitaires de France, 2000), 15). The inquisitorial procedure (cf. infra), on the other hand, where the accused faces the authorities - and therefore the represented collectivity - as his direct opponent, is more easily relatable to the all-against-one scheme marking the apogee of any sacrificial crisis. To close our argument, we remind that ritual, not unlike the ancien régime's legal order, aims to free the community from disorder (Girard, La violence, 167). We do, however, not want to imply that every aspect of criminal procedure (or law) could be neatly traced back to sacrificial rituals. This would be grossly overplaying our hand. Conceivably, there are multiple origins and no doubt these fields have developed an internal logic and dynamic independent of their proposed sacrificial inheritance. 
(historically speaking) in a sometimes equally sanguinary spectacle. ${ }^{40}$ By anchoring its ritualistic structure in the law of proof, criminal law became Janus-faced, being at the same time the 'via dolorosa' leading towards Golgotha and the roadblock to cut this blood-stained pathway off. The more serious the obstacles to be overcome on the road towards punishment, the more demanding the standard of proof and the more humane the ways of securing the evidence, ${ }^{41}$ the less are the odds of punishing the innocent and the further away from 'primitive' sacrifice we are, it seems. Latour says: 'la qualité propre [d'un jugement] dépend de la longue hésitation avec laquelle on l'attache'. 'Sans hésitation, pas de droit'. 'Est-ce bien

40 We think there might be a case to interpret most types of ius commune punishment, also anemic ones, as exhibiting scapegoat-dynamical features, but this falls beyond the scope of this essay. Some fragmentary suggestions will, however, be offered. Capital punishments and mutilations are relatively easily connected to a sacrificial origin (see also notes 23 and 27). Carbasse writes on the death penalty that it originally had 'le double caractère de d'un sacrifice expiatoire et d'un rite d'expulsion.'. (Carbasse, Histoire du droit, 14). Since Girard deems scapegoat dynamics to be at hand both in sacrificial rites as in rites of expulsion (Girard, Le bouc, 35; Girard, La violence, 130, 143), exile, banishment, and to some extent excommunication, are no unsurmountable hurdles for Girardian hermeneutics. The same goes for civic death, which is a symbolical expression of exclusion. Also, in the early modern punishments as the galleys or workhouse or in the prison system as a whole, a type of ban or expulsion might be in play. It must be added that to grasp what is at stake in these various types of exclusion, an author like Agamben probably offers an alternative or complementary and possibly more fine-tuned hermeneutical inroad than Girard's (for more on the Agambenian ban or ex-ceptio, see for instance: Giorgio Agamben, Homo Sacer: Sovereign Power and Bare Life (Stanford: Stanford University Press, 1998), 17-8, 28). In shame punishments, a type of 'official lynch justice' is discernable (James Q. Whitman, 'What is Wrong with Inflicting Shame Sanctions?'’ The Yale Law Review 107(4) (1998): 1095). Compositions or fines are harder nuts to crack and prima facie one could easily be misled to think they could not have anything to do whatsoever with sacrifice or scapegoat dynamics, but Laum traced the origins of money to value-equivalence for sacrificial animals in Homer's world (Bernhard Laum, Heiliges Geld: Eine historische Untersuchung über den sakralen Ursprung des Geldes (Berlin: Semele Verlag, 2006)), Smith mentions atonement payments were made as satisfaction for offences in Semitic sanctuaries, either in the form of a sacrificial animal or in money (Robertson Smith, Lectures on the Religion of the Semites: The Fundamental Institutions (London: Adam and Charles Black, 1984), 346-8) and Whitman, to whom we are much indebted, points to a sacrificial scenery when treating archaic compositions for talionic mutilations (Whitman, 'At the Origins,' passim; with regards to the Middle Ages see Gunter Gudian, 'Geldstrafrecht und Peinliches Strafrecht im späten Mittelalter,' in Rechtsgeschichte als Kulturgeschichte: Festschrift für Adalbert Erler zum 70. Geburtstag, ed. Hans-Jürgen Becker and Gerhard Dilcher e.a. (München: Scientia Verlag Aalen, 1976)). In general, punishment was a ritual degradation and is about 'treating people as inferiors' (James Q. Whitman, Harsh Justice: Criminal Punishment and the Widening Divide between America and Europe (Oxford: Oxford University Press, 2003) 20, quote on 26). Therefore, it creates exactly the kind of socially isolated and despised 'scum' scapegoat dynamics could further prey on.

41 Although the humanization of criminal law is debatable, we side with Schmoeckel and Whitman that in Europe this is the general historical trend. On the abolition of torture, the former says: 'Zum ersten Mal setzte eine gesetzliche Neuerung eine Forderung der Humanität durch und verwies die Staatsraison auf den zweiten Platz. [...] Die Begriffe "Humanität» und "Staatsraison» signalieren eine Wertentscheidung, die dem Schutz des Menschen einen Vorrang läßt. Diese Wertung ist zur Grundlage der westlichen Kultur geworden' (Schmoeckel, Humanität, 591-2; see also Whitman, Harsh Justice, 84-95). 
jugé? Oui, pourvu qu'on a bien hésité. ${ }^{42}$ The more ready, on the other hand, a society is to sweep aside, by means of exceptions, any obstacles on the via dolorosa, the more it moves away from the legal universe as we understand it today, towards a sacrificial mentality. Blackstone for instance defends the rule that two witnesses are necessary for a conviction of treason 'to secure the subject from being sacrificed to fictitious conspiracies' ${ }^{43}$ Historical development seems to have tipped the balance in favour of the defendant, maybe by using the law of proof as an antidote for sacrificial venom. If there was a gradual evolution from sacrifice to criminal law, as Girard claims, one could expect to find more sacrificial tendencies in 'less developed' or more 'primitive'44 legal systems. The hunting ground we have in mind is the ius commune, whose salient features can be better understood in contrast with a modern account of the presumption of innocence, which we will provide in the following section.

\section{A modern account of the presumption of innocence}

In the context of the criminal trial, the presumption of innocence implies that the judge/jury is to presume the defendant innocent of the offence he stands trial for. He will not be convicted or punished unless the presumption of innocence is defeated by 'proof of guilt to the requisite standard'. ${ }^{45}$ Duff recently argued to

42 Bruno Latour, Enquête sur les modes d'existence: Une anthropologie des Modernes (Paris: La Découverte, 2012), 365, 367.

43 William Blackstone, Commentaries on the Laws of England: A Facsimile of the First Edition of 17651769 (Chicago: University of Chicago Press, 1979), Volume 4, Article 3, Section 3, Clauses 1 and 2, Document 8, <http://press-pubs.uchicago.edu/founders/documents/a3_3_1-2s8.html> (accessed 22 February 15).

44 The concept 'primitive' has become 'anathema in anthropology today', says Geertz (Armin W. Geertz, 'Can we Move Beyond Primitivism? On Recovering the Indigenes of Indigenous Religions in the Academic Study of Religion,' in Beyond Primitivism: Indigenous Religious Traditions and Modernity, ed. Jacob K. Olupona (New York: Routledge, 2004), 52). Another of the concept's vigorous critics is more nuanced: 'Sometimes we can unquestionably determine that some single items or usages of a culture are more inferior [...] than others [...] in other cultures. [..W]e can speak of a more primitive way of crime detection and a less primitive one', without risking 'serious disputes' (Francis L.K. Hsu, 'Rethinking the Concept «Primitive»', Current Anthropology, 5, 3 (1964): 174 (our italics)). A definition of 'crime detection' is: 'The process of uncovering criminal activity (or verifying reported crime) and acquiring evidence in order to identify and prosecute its perpetrators' (see <www.oxforddictionaries.com/definition/english/crime-detection> (accessed 4 March 2016)). Since this is related to the subject of our paper, we will use terms like 'primitive' or 'less developed', denoting merely a degree of inclination towards an institutionalized scapegoatdynamical strategy to cast blame, resolve conflict, or social tension. A word as 'tribal' or 'indigenous' is no alternative, since scapegoat dynamics are not restricted to those types of communities, they also flourish in so-called 'civilized' societies. The main issue/criterion is therefore to what extent they are institutionalized. A tendency towards moral evolutionism in Girard's work is undeniable. Questionable as this might be, it is defendable. After all, morally unjustifiable sacrificial logic is the core argument against consequentialism, which is so tangible in scapegoat dynamics (cf. Caiaphas' dictum: 'better that one man die for the people than that the whole nation perish') (John, 11:50; Girard, Le bouc, 163).

45 Antony Duff, 'Who Must Presume Whom to Be Innocent of What,' Netherlands Journal of Legal Philosophy 3 (42) (2013): 170. 
enhance our understanding of the way the presumption of innocence functions by considering the different normative roles involved in the system of criminal justice. Each role, such as suspect, defendant, or convicted offender, comes with specific burdens, rights, and responsibilities. A defendant has for instance the right to appear in court, enter a plea, etc... The presumption of innocence not only protects him from unwarranted conviction but also from having to carry the burdens attached to the role of defendant without sufficient evidence to justify this step. Once put in the role of defendant, a qualified rather than defeated presumption of innocence is at work. One cannot consider him guilty, but if he were to be considered totally innocent, he would not stand trial. One cannot impose upon him the role of offender, the burden of which are punitive measures, unless convicted. If the verdict is 'not guilty', the role of defendant has reached an end and the subject in question can no longer be considered a suspect. The presumption of innocence operates, according to Duff, beyond the narrow scope of the criminal trial since the presumption of innocence that protects us from readily becoming a defendant is one that protects all citizens. The presumption of innocence is therefore rooted in a broader notion of civic trust: citizens should be trusted unless their behaviour proves them unworthy of trust. A well-functioning society cannot function absent civic trust. Hence, a possible role wherein acquitted defendants would still be considered guilty is to be rejected as incompatible with the social glue of civic trust. The roles of suspects and defendants, towards whom the civic trust is qualified, are to be strictly limited in time. ${ }^{46}$

\section{Criminal law in the ius commune}

\section{Mala fama and the inquisitorial trial}

Before the thirteenth century, the criminal trial followed an accusatorial procedure (processus ordinarius). ${ }^{47}$ The authorities could not investigate a crime ex officio. Instead, an accuser had to press charges. He was responsible to provide proof, namely two reliable eyewitnesses of the offence, sub poena talionis. This meant that when he failed to deliver proof, he would suffer the punishment due for the offence of which he accused his opponent. ${ }^{48}$ Furthermore, he could be forced at the request of the accused to prove his accusations by engaging in a deadly trial by battle. God would then be the judge of the truthfulness of his assertions. ${ }^{49}$ Since accusations were so dangerous, frequently nobody stepped forward. As a last resort, a judicial ordeal could be organized. Generally, these judgements of God were imposed upon someone of ill repute, suffering from what jurist called mala

46 Duff, 'Who Must,' 172-80.

47 We must note, however, that there was not yet a clear distinction between criminal and civil law. Lotte Kéry, 'Inquisitio-denunciatio-exceptio: Möglichkeiten der Verfahrenseinleitung im Dekretalenrecht,' Zeitschrift der Savigny-Stiftung für Rechtsgeschichte 87 (118) (2001): 230.

48 Ruud G.W. Huysmans, 'The Inquisition For Which the Pope Did Not Ask Forgiveness,' The Jurist 66 (2006): 471.

49 Whitman, The Origins, 60, 80. 
fama: 'idest quod sit publica vox et fama quod ille sit culpabilis'. ${ }^{50}$ The community had named a suspect and declared his guilt. ${ }^{51}$ This shows the ordeals could thrive on scapegoat dynamics so intimately linked with the presumption of guilt. Judgement and its bloody consequences were then rooted in the sacred, whose true core, according to Girard, is collective violence. Applying our Girardian hermeneutics, we could argue that in 1215, the Fourth Lateran Council, under Innocent III, took a fundamental step towards extricating this 'primitive' nexus of violence and the sacred, by forbidding priests to further provide the blessings necessary for the ordeal to be effective. ${ }^{52} \mathrm{~A}$ new and more efficient way of dealing with crime was introduced: the inquisitorial procedure (processus extraordinarius). As was the case with the ordeal, this new procedure was a response to mala fama. ${ }^{53}$ By denunciation, public scorn could be brought to the attention of the judge, who then launched an inquisitio famae to establish the quality of the origin of the rumour. It must be widespread, spring from good and respectable people (boni et graves), and two integer witnesses had to testify the existence of the hearsay. Some lawyers, however, allowed the rumour to spring even from the defendant's enemies. ${ }^{54}$ To counter mala fama, an oath (purgatio canonica) could be sworn, provided the defendant could find enough oath helpers willing to swear they believed his denial of guilt. ${ }^{55}$ Since swearing idle meant eternal damnation, medieval man took this very seriously ${ }^{56}$ and oath helpers could prove to be a rare commodity. If the defendant succeeded, he was freed from suspicion and restored in bona fama. ${ }^{57}$ If not, an inquisitio veritatis, an investigation into the truth of the matter, was initiated. The judge could, however, also decide to omit the inquisitio famae (hereby refuting the defendant the possibility of compurgation) and immediately launch the inquisitio veritatis. The revolutionary aspect of the inquisitorial procedure was that the judge could also proceed ex officio, without a denunciation or an accusation as preliminary conditions, merely by lending his ears to rumours he overheard. Mala fama, clamouring insinuations (clamosa insinuatio), a public outcry, scandal, and in some cases mere suspicion could set the inquisitorial trial in

50 Proposed translation: 'this is that the voice of the people and rumor have it that he is guilty', see Albertus Gandinus, 'Tractatus de malificiis,' in Tractatus Diversi Super Maleficiis (Lugduni: apud heredes J. Juntae, 1555), rubr. Quomodo de malefciis cognoscatur per inquisitionem; also quoted by Whitman, The Origins, 61, 230, n.26. Whitman, The Origins, 73.

52 Whitman, The Origins, 53.

53 In fact, it was rooted in an already existing infamatio-procedure. See Kéry, 'Inquisitio,' 232-3.

54 Kéry, 'Inquisitio,' 232-3, 256-7.

55 Henry Ansgar Kelly, 'Inquisition and the Prosecution of Heresy: Misconceptions and Abuses,' in Henry Ansgar Kelly, Inquisition and Other Trial Procedures in the Medieval West (Aldershot: Ashgate, 2001), 444.

56 Whitman, The Origins, 77.

57 Julien Théry, 'Fama: l'opinion publique comme preuve judiciaire,' in La preuve en justice de l'Antiquité à nos jours, ed. Bruno Lemesle (Rennes: les Presses Universitaires Rennes, 2003), 127. 
motion. ${ }^{58}$ Mala fama, functioning by a fictio legis ${ }^{59}$ as denunciator or accuser ('quasi denunciante fama vel deferente clamore'), 60 had hereby been given almost legal personality, Théry observes. ${ }^{61}$ Conceptually, the maxim that the prosecuting party could not at the same time be the judge of the matter was in this way adhered to, ${ }^{62}$ but de facto these normative roles merged in the ius commune judge. ${ }^{63}$ In present days, the presumption of innocence protecting us from having to stand trial is exerted by the public prosecutor. ${ }^{64}$ When qualified by the role of defendant, the judge will independently re-evaluate the charge, again employing the presumption of innocence, this time in the context of a trial. The office of public prosecutor only emerged during the French Revolution and in Germany in the course of the nineteenth century. ${ }^{65}$ Hence, ius commune judges were at the same time responsible for truth-finding and truth-saying. They could in general not declare the accused guilty without proof (cf. infra), but the fact that they themselves harboured enough suspicion to qualify the presumption of innocence and start the prosecution put the defendant in an awkward position and would be incompatible with the contemporary presumption of innocence. Therry interpreted the judge's competence to evaluate fama as a significant instrument of power. The social phenomenon of fama needed validation by a judge to generate legal consequences. And these could be far reaching, since fama did not only launch but also moulded procedure. Mala fama was the judge's guideline in search of credible witnesses, could warrant the use of torture, functioned as a minor proof (cf. infra), and was used in verdicts to motivate the infliction of punishment. The twelfth and thirteenth century architects of the legal concept fama 'donnaient ainsi force de droit au discrédit moral et social frappant celui 'dont on parlait mal' (de quo malo loquuntur)'. ${ }^{66}$ In the thirteenth century, jurists were even inclined to regard all people of degrading profession or pertaining to the lower social strata as infamous. ${ }^{67}$ Mala fama, we could paraphrase, was attached to those marginal social elements which were most likely to attract unsubstantiated accusations and mob violence, according to Girard. Tantalizing is therefore the legal fiction that mala fama was to be considered as the accuser. By 1250, the monopoly on violence was already established enough ${ }^{68}$ to enable embryonic states to exert the violence, but the mob still largely singled out on whose head the hammer would fall. Mala fama, this power-related junction of social and politico-juridical order, is

58 Kéry, 'Inquisitio,' 243; Richard Helmholz, 'Scandalum in the Medieval Canon Law and in the English Ecclesiastical Courts,' Zeitschrift der Savigny-Stiftung für Rechtsgeschichte, Kanonistische Abteilung 258 (2010): 264-6.

59 William Richardson, The Presumption of Innocence in Canonical Trials of Clerics Accused of Child Sexual Abuse (Leuven: Peeters, 2011), 23.

60 Proposed translation: 'as if reputation was denouncing or an outcry was accusing'.

61 Théry, 'Fama,' 129-30.

62 Kéry, 'Inquisitio,' 240.

63 Richardson, The Presumption, 22.

64 Duff, 'Who Must,' 175.

65 In England, the institution was developed earlier. See Schmoeckel, Humanität, 424.

66 Théry, 'Fama,' 141.

67 Théry, 'Fama,' 132, 138, 141, 145, 147.

68 Whitman, The Origins, 42, 57. 
a legal concept operating in the spirit of scapegoat dynamics. It attests to a very peculiar phenomenon, which we propose to coin as 'legal conceptualization of scapegoat dynamics'. By legally codifying sometimes vicious aspects of mob psychology, the law participates in scapegoat dynamics and at the same time reveals them. Only by bringing to the fore 'des choses cachées depuis la fondation du monde' (i.e., scapegoat dynamics), these might be one day subsequently attacked and set aside. ${ }^{69}$

Before we continue, let us bear in mind that whereas today's criminal procedure should be informed by the presumption of innocence, the ius commune's inquisitorial trial was generally permeated by a presumption of guilt in the guise of mala fama, or at the very least, a presumption of innocence seriously qualified by the judge's own appreciation.

\section{The law of proof and the presumption of innocence}

Prima facie the law of proof applied in criminal cases was very strict. Conviction required proof of guilt, rather than mere suspicion. Proof should provide total certainty of the matter at hand, being 'luce clarior meridianis'. ${ }^{70}$ The standard of full proof (probatio plena) was met only by two credible eyewitnesses of the offence, a solid written proof or a confession. ${ }^{71}$ Circumstantial evidence (indicia) was deemed insufficient. ${ }^{72}$ When in dubio: pro reo. These mantras were recited throughout the centuries. Although they were taken very seriously, things were much more complex as various doctrines were developed to ensure punishment when the standard of proof was not met, as we shall see. Langbein interpreted the law of proof as originally designed to eliminate judicial discretion. If judges had to switch seats with God after the disavowal of the ordeal, there was no room for doubt. For human judgement to be commonly acceptable, the judge had to deliver his verdict based on objective criteria, as an 'automaton'. ${ }^{73}$ Schmoeckel, however, has convincingly shown that judicial discretion (arbitrium iudicis), in many ways determining the course a trial would take, was always part and parcel of the ius commune. ${ }^{74}$ The bulk of the cases lacked sufficient evidence and needed to be interpreted. This was tricky business since anything less than probatio plena plunged the judge into a true labyrinth of unsystematised, poorly distinguishable, overlapping, ill-defined, and author-dependant legal concepts indicating minor proof (probatio semiplena, indicium dubitatum/indubitatum, praesumptio), each of

70 Proposed translation: 'clearer than the midday sun', C. 4,19,25.

71 Schmoeckel, Humanität, 193-6, 207.

72 John H. Langbein, Torture and the Law of Proof: Europe and England in the Ancien Régime (Chicago: The University of Chicago Press, 1976), 4.

73 Langbein, Torture, 6-7.

74 Schmoeckel, Humanität, passim. See also Richard. M. Fraher, 'Conviction According to Conscience: the Medieval Jurists' Debate Concerning Judicial Discretion and the Law of Proof,' Law and History Review 7(1) (1989); Bernard Schnapper, 'Les peines arbitraries du XIIe au XVIIIe siècle (Doctrines savants et usages français),' Tijdschrift voor rechtsgeschiedenis 41 (1973). 
which, to make things even less transparent, had multiple subdivisions. ${ }^{75}$ In contrast to their definition, these had strictly delineated evidential value and procedural consequences (e.g., whether torture was allowed). Hazy concepts with clear probative value enabled the judge, within boundaries, to subsume circumstantial evidence in the legal concept he deemed fit according to the probative value and subsequently the procedural track he had in mind. ${ }^{76}$ Obviously, this put the defendant in somewhat of a scrape.

One of those minor proofs was the praesumptio iuris, of which mala fama is an example. ${ }^{77}$ As Schmoeckel explains, there were presumptions à charge, like mala fama, or à décharge, like the presumption of innocence, and these could sometimes level each other out. They were used to reinforce other proofs and to motivate verdicts. Presumptions warranted the use of torture or rather raised the requirements for its appliance or for reaching a conviction. ${ }^{78}$ The presumption of innocence, formulated by Monachus († 1313) as item quilibet presumitur innocens nisi probetur nocens ${ }^{79}$ was thus a cog of minor importance in the law of proof. The presumption of innocence evolved, as Köster shows, from a broader presumption of goodness - making Duff's attempt to embed the presumption of innocence in civic trust historically speaking all the more relevant. However, in secular law, these presumptions were not originally principles of natural law applying indiscriminately to all. As proofs, they rather functioned as legally codified value judgements, deduced from behaviour or social status. ${ }^{80}$ Farinacius (1544-1618) writes: 'multo magis praesumitur bonus, is qui nobilis aut dives est: sicut enim de paupere et populari, ut plurimum praesumitur malum, cum facile censeatur corrumpi' ${ }^{81}$ In principle, the presumption of innocence could protect against a denunciation of the existence of mala fama, but two witnesses asserting mala fama already overruled the presumption of innocence. The maxim could even work against the defendant: as a praesumptio generalis it was equally applicable to other normative roles than the defendant. If doubts arose concerning the trustworthiness of the witnesses à charge, the presumption of innocence based on their good reputation could be used to rule these out. The presumption of innocence could cancel out

75 Schmoeckel, Humanität, 210, 270.

76 Schmoeckel, Humanität, 272.

77 Théry, 'Fama,' 141.

78 Schmoeckel, Humanität, 428.

79 Proposed translation: 'moreover is anyone presumed innocent unless proven guilty'. See Pennington, 'Innocent,' 115, (also n. 24). Some scholars argue the roots of the presumption of innocence are to be found even in the early Middle Ages. See Richard M. Fraher, " Ut nullus describatur reus prius quam convincatur»: Presumption of Innocence in Medieval Canon Law?', in Proceedings of the Sixth International Congress of Medieval Canon Law, ed. Stephan Kuttner and Kenneth Pennington (Città del Vaticano: Bibliotheca Apostolica Vaticana, 1985), 493-506.

80 Rolf-Jürgen Köster, Die Rechtsvermutung der Unschuld (Inaugural-Dissertation) (Bonn: 1979), 8-28.

81 Proposed translation: "who is rich or noble is much stronger presumed to be good, just as for instance evil is generally presumed of a pauper or commoner, since he is thought to be easily corruptible'. See Prospero Farinacius, Praxis et theoricae criminalis (Frankoforti ad Moenum: typis Hartmanni Palthenii, sumptibus haeredum D. Zachariae Palthenii, 1622), fol. 743, amplia III, col. 280; also quoted by Köster, Die Rechtsvermutung, 29. 
only doubtful circumstantial evidence (indicia dubitata) and was swept aside by stronger evidence (indicia indubitata). As a cog in the law of proof, as an evaluation of general conduct rather than as principle informing the law of proof, the presumption of innocence hardly provided the defendant any protection at all. ${ }^{82}$ Alciatus (1492-1550) puts it very sharply: 'Innocens praesumitur, quem nullus accusavit'. ${ }^{83}$ Medieval canon lawyers independently elaborated the presumption of innocence as a maxim of natural law. Universalizing its application rather than restricting it to people of high standing seems to have had only theoretical implications in early modern secular receptions: it merely legitimated the already existing criminal law principle of assigning the onus probandi to the plaintiff or the inquisitorial judge. ${ }^{84}$

We now clearly perceive that the presumption of innocence was not a hegemonic principle determining and structurally confining the law of criminal procedure. As minor element within the law of proof, sheltering only the socially esteemed and leaving marginal elements exposed, it could even serve the scapegoat dynamics we deem to be sometimes at work in the criminal trial. Compared to the presumption of innocence, mala fama was a more fundamental but far less innocent determinant of the inquisitorial trial.

\section{Torture}

Bloodshed, intimately linked to the collapse of the social order (war, disease), was taboo in archaic religion. It was restricted to ritual sacrifice, says Girard. ${ }^{85}$ Christ's innocence may have prompted Early Christian doctrines to insert the question of guilt into the equation. The criminal trial, explains Whitman, soon had to operate under what I would like to paraphrase as a 'taboo' on unlawfully shed blood. Since judges were no less involved in judicial bloodshed than 'primitive' priests were in sacrifice, a theology of guilt-oriented just judging entered the scene. ${ }^{86}$ At stake was not only life and limb of the accused but also the salvation of the judge's soul. Unlawful judicial bloodshed would result in eternal damnation. Whitman claims criminal procedure to be as much about fact-finding as about providing moral comfort for the judge. Only when procedure was followed (iuris ordine servato), the judge's dread of hellfire could be soothed by Augustine's dictum: 'Cum homo iuste occiditur, lex eum occidit, non tu' ${ }^{87}$ Moral comfort procedures entailed shifting the blame of judgement to someone else than the judge. As the buck was passed

83 Proposed translation: 'he is presumed innocent, whom nobody has accused'. See Andreas Alciatus, De praesumptionibus tractatus Aurei Iuris cum Argumentis et Annotationibus de Ioan. Arelatani (Frankoforti ad Moenum: B. Nikolaus, 1580), regula III, praes. 4, fol. 252, col. 3; also quoted by Köster, Die Rechtsvermutung, 33.

84 Köster, Die Rechtsvermutung, 23-7, 29-34.

85 See for instance, Girard, La violence, 55 and passim.

86 We have injected some Girardian themes in Whitman's stimulating account: Whitman, The Origins, 33.

87 Proposed translation: 'when a man is killed justly, it is the law that kills him, not you'. See Aurelius Augustinus, Quaestiones in Heptateuchum libri VII (Turnholti: Brepols, 1958), 221, Quaest. Lev. Qu. 68; also quoted by Whitman, Origins, 39. 
to God in the ordeal, after 1215, other victims had to be found. The witnesses and the accused were now put under pressure to deliver the fatal blow necessary to reach a conviction, hereby deresponsibilizing the judge. Moral theology declared it a mortal sin for witnesses not to speak up, for instance in the case of fama. But let us now focus on the accused, who could be tortured into confession. ${ }^{88}$

Torture, concomitant to the rise of the inquisitorial procedure, was the central pillar of the law of proof. Its ratio essendi is commonly connected to the high standard of proof advancing confession as regina probationum. ${ }^{89}$ Torture, usually exerted in relation to serious crimes or when no other modes of proof were available, was by no means imposed indiscriminately, Schmoeckel explains. Azo ( $\dagger$ 1220/1229) put the probatio semiplena, one eyewitness, as prerequisite. According to other authors, the accumulation of minor indications of guilt acquired the value of a probatio semiplena, substantially lowering the standard of proof for putting someone to the question. Also weighty presumptions were used to legitimate torture. Debated was whether mala fama sufficed as well. ${ }^{90}$ Gandinus († 1310) left this to the discretion of the judge. Hyppolitus de Marsilliis (1581) deemed rumour or denunciation to be sufficient cause. To ensure the credibility of tortured confessions, the defendant had to confirm his statements on other occasions. When he refused this, he could be tortured again. Retracted confessions still counted as half a proof, which could now be accumulated with the half proof that warranted torture in the first place. Hence, the standard of proof needed for conviction was met. In cases where torture was not allowed, defendants were nonetheless frequently told they would be tortured and were escorted into the torture room (territio). The mere sight of the gruesome equipment proved to be highly effective in reaching confessions. ${ }^{91}$ The usual moderation in the administration of torture was, however, defenestrated in dealing with typical scapegoats as witches and heretics. These crimes left no material traces. Judges could nevertheless proceed to torture with virtually nothing else to go on but suspicion. ${ }^{92}$ The ius commune did not solely regard torture as a means to gather evidence. The Ordonnance Criminelle from 1670 lists it as punishment. Providing evidence and punishment at the same time, torture was utterly incompatible with the modern conception of the presumption of innocence, according to which nobody is to be punished without proof of guilt. ${ }^{93}$ Exerted on the accused, torture was by consequence a punishment for mere suspicion, which often seems to have been linked, once more, to mala fama. Fiorelli has established that most Italian city-states were not keen on inflicting torture on people of good repute. ${ }^{94}$ On the other hand: 'La

88 Whitman, The Origins, 1-124.

89 Langbein, Torture, 4-5; Schmoeckel, Humanität, 236-7.

90 For reservations concerning fama, see J. Ph. Lévy, La Hiérarchie des preuves dans le droit savant du Moyen-Âge depuis la Renaissance du Droit Romain jusqu'à la fin du XIVe siècle (Lyon: Annales de l'université de Lyon, 1939), 114-5.

91 Schmoeckel, Humanität, 254-67.

92 Schmoeckel, Humanität, 258-9.

93 Schmoeckel, Humanität, 427.

94 Piero Fiorelli, La tortura giudiziaria nel diritto comune, Vol. I (Varese: Giuffré, 1954), 91-4, nn. 22-32. 
torture devint le propre de la "procédure extraordinaire", qui était la règle [...] pour les "larrons", individus "de mauvaise vie" et autres accusés incapables de faire valoir auprès du tribunal l'estime de gens de bien', writes Théry. ${ }^{95}$ While usually thriving on the presumption of guilt, torture did not even need that much: even the plainly innocent witness could be tortured if his statements were contradictory and he must be brought 'to his senses' ${ }^{96}$ Torture is truly an institution meant to facilitate convictions. Whether the defendant got a fair chance depended largely on the arbitrium iudicis: the judge decided if and to what extent torture was inflicted, depending on his interpretation of the severity of the crime, the evidence at hand, and the social status of the accused. ${ }^{97}$

This leeway made torture highly suitable to serve scapegoat dynamics since it allows a highly aleatory method for establishing guilt to take root at the heart of procedural law. Moreover, torture's affiliation with mala fama and accusations of horrendous crime suggests nothing less than a strong connection to the sacrificial order. The rise and proliferation of torture was furthermore a consequence of its proven efficiency in trials against heretics, medieval scapegoats par excellence, since the late twelfth century. ${ }^{98}$ Although torture remained alive and kicking until deep in the eighteenth century, its venomous injustice was noticed by contemporaries centuries before its abolition. In his outstanding work on torture, Schmoeckel has gathered these critiques, some of which pinpoint with astonishing accuracy the scapegoat dynamics we deem to be at hand. Vives (1493-1540) wrote: 'fateantur fictum crimen de supplicio certi, ne torqueantur'. ${ }^{99}$ Montaigne (1533-1592) perceived thousands of false confessions resulting in 'tuer sans occasion'. ${ }^{100}$ Grevius (1580-1630) attacks the fact that nothing but slander would prompt torture. Von Spee's Cautio Criminalis (1631) on witch trials explains the duress and repetition of torture made it virtually impossible to escape conviction. Torture 'produces' guilt of nonexistent crimes in an arbitrary way, he says. De La Bruyère (1645-1696) explains that because of torture nobody could consider himself safe not to be one day innocently executed. Bernhardi (1705) complained torture merely delivered an outer appearance of justice. ${ }^{101}$ To summarize these findings in a unified way: torture makes it possible that arbitrarily chosen innocent victims, ${ }^{102}$ falling prey to slanderous accusations, are being killed without reason

95 Théry, 'Fama,' 138.

96 Whitman, The Origins, p. 104.

97 Schmoeckel, Humanität, 267, 270.

98 Fraher, 'Conviction,' 62; Schmoeckel, Humanität, 106.

99 Proposed translation: 'due to real pain, they would confess an imagined crime, in order not to be tortured'. Interestingly, 'supplicium' also means sacrifice. See Aurelius Augustinus, De civitate Dei, ed. Juan Luis Vives, 19, 6, De errore humanorum iudiciorum, cum veritas latet (Lutetiae: in aedibus Carolae Guillard, 1544), 247; also quoted by Schmoeckel, Humanität, 115.

100 Michel de Montaigne, 'De la conscience', in Essais, 2, 5, ed. Pierre Villy (Paris: P.U.F, 1992), 369; also quoted by Schmoeckel, Humanität, 124-5.

101 Schmoeckel, Humanität, 120-1, 133, 139-40, 149.

102 The qualifications uttered in note 26 may apply, but Schmoeckel is clear: 'keiner konnte [...] sicher sein, nicht selbst einmal als Unschuldiger hingerichtet zu werden. Eine solche Gefahr konnte nur durch die Folter entstehen' (Schmoeckel, Humanität, 133 (our italics)). 
for imaginary crimes they did not commit. The affinity to scapegoat mechanisms, these fictions of justice, can hardly be denied. And the contrast with the contemporary presumption of innocence could not be more explicit.

\section{Ordo non servatus}

For extra-ordinary crimes, there were extra-ordinary measures. 'Procedural anomalies', ${ }^{103}$ the extra-ordinem, were permitted when facing crimina atriciora/enormia. ${ }^{104}$ Lacché has grouped the crimina atrociora as being infractions of the religious order (heresy, sacrilege, blasphemy, sodomy...), attacks on the political foundations (crimen laesae maiestatis), ${ }^{105}$ or particularly serious blood crimes (murder, parricide...). Whomever committed these atrocities was considered a hostis omnium, patriae et fidei. ${ }^{106}$ Since the reipublicae salus ${ }^{107}$ was felt to be in peril, a relentless response could be administered by the penal system, which was on this occasion largely discharged from following the ordo iuris prescribing due process. It now entered the ordo non servatus. In case of heresy and crimen laesae maiestatis, considered to be identical crimes since Innocence III (1198-1216), ${ }^{108}$ the standard of proof was lowered (presumptions of guilt now were enough for imposing death penalty (also in case of murder)), torture could be inflicted even if there was not enough proof to warrant this, witnesses deemed unreliable in other contexts were allowed (like former criminals, heretics, people of ill-repute, minors, drunks), ${ }^{109}$ rights to be assisted by an attorney, to appeal or the possibility to receive mercy were annulled, and the death penalty was executed in the most cruel way. ${ }^{110}$ This ordo non servatus aiming at swift and efficient repression was legitimated by a doctrine of reason of state, framed by Innocent III (1198-1216) as 'rei publicae interest ne crimina remaneant impunita' ${ }^{111}$ Farinacius writes: 'quia in atrocissimis licitum est iudici iura transgredi; requisitas solemnitates

103 Lacché, 'Ordo,' 364.

104 'Atrox' means: hideous, cruel, savage, horrible, atrocious, severe ...'Enormis': huge, out of line, irregular. We will treat these crimes as belonging to the same category, although there were differences. Both crimina atrociora and enormia were very vague concepts with enough in common to allow for them to be treated together. For more information, see Julien Théry, 'Atrocitas/enormitas: Pour une histoire de la catégorie d' "énormité" ou “crime énorme” du Moyen Âge à l'époque moderne' Clio@Themis: revue éléctronique d'histoire du droit 4 (2011).

105 Lese-majesty.

106 Proposed translation: 'an enemy of the people, the fatherland, and faith'.

107 Proposed translation: 'the salvation of the commonwealth'. See Lacché, 'Ordo,' 364, 380.

108 Jacques Chiffoleau, 'Le crime de majesté, la politique et l'extraordinaire: Note sur les collections érudites de procès de lèse-majesté du XVII siècle et sur leurs exemples médiévaux,' in Les procès politiques (XIVe-XVIIe siècle), ed. Yves-Marie Bercé (Rome: École française de Rome, 2007), 613.

109 Kéry, Gottesfurcht, 296-7; Lacché, 'Ordo,' 382.

110 Schmoeckel, Humanität, 277-8.

111 Proposed translation: 'it is in the interest of the commonwealth that crimes should not be left unpunished'. See Richard M. Fraher, 'The Theoretical Justification For the New Criminal Law of the High Middle Ages: “rei publicae interest ne crimina remaneant impunita”,' University of Illinois Law Review 3 (1984): 577, 581, passim. 
non adhibere; \& ordo est ordinem non servare'. ${ }^{112}$ By this remarkable flexibility (' $m o l-$ lis lex, sed lex' $)^{113}$, the ius commune allows for its partial suspension and enters the state of exception, which is not all-encompassing as Schmitt describes it, ${ }^{114}$ but whose very specificity and partiality is instead most revealing. The ordo non servatus suspends exactly these hallmarks of due process that could stand in the way of an aleatory selection of the legal order's victims: banning attorneys and appeal are no doubt crucial infringements of the rights of defence, but even more important are the suspension of a demanding standard of proof and of restrictions on torture and witnesses. In as far as legal order was desacr(ifici)alized by impeding public vengeance to strike in an aleatory way, its (partial) suspension takes the shape of a regression towards the aleatory realm of sacrificial order. The ordo of the ordo non servatus could be interpreted as pertaining to the scapegoat-dynamical infrastructure of criminal law. Schmitt is worth quoting to grasp the interconnection we want to establish between both orders, as he states: 'Weil der Ausnahmezustand immer noch etwas anderes ist als eine Anarchie und ein Chaos, besteht im juristischen Sinne immer noch eine Ordnung, wenn auch keine Rechtsordunung. [...] Die zwei Elemente des Begriffes "Rechts-Ordnung" treten hier einander gegenüber und beweisen ihre begriffliche Selbständigkeit'. ${ }^{115}$ The prerogative to declare this state of exception found in the ordo non servatus was reserved for the princeps legibus solutus. The highest courts, where the judge acted as the king's proxy, delivered justice tapping from royal authority. ${ }^{116}$ Whether a crimen was atrocius/enorme was left to the arbitrium iudicis. For later sixteenth century France, Schnapper deems it to have become hardly distinguishable from the judicial power of the prince. He writes: 'Le pouvoir discrétionnaire des juges fit des progrès inquiétants: non seulement on leur reconnut parfois le droit de punir des actes non réprimés par le droit positif [ou] de prononcer des peines de mort sans habilitation légale si le crime leur paraissait atroce [...], mais encore on leur permit de condamner sans preuve, sur présomptions'. ${ }^{117}$

Théry and Chiffoleau have, respectively, shown that the categories of enormitas and crimen laesae maiestatis ${ }^{118}$ were so loosely defined they could be extended

112 Proposed translation: 'because in dealing with the most horrendous crimes it is allowed that the judge transgresses rights, that the required formalities are not applied and that procedure consists in the non-observance of procedure'. See Farinacius, Praxis, I, q.37, n.86, 586; also quoted by Schmoeckel, Humanität, 276.

113 Proposed translation: 'flexible law, yet law it is'. See Bruno Latour, La fabrique du droit: Une ethnographie du conseil d'État (Paris, La Découverte, 2004), 69.

114 Schmitt writes on the state of exception: 'der Souverän [...] steht Außerhalb der normal geltenden Rechtsordnung und gehört doch zu ihr, denn er ist zuständig für die Entscheidung, ob die verfassung in toto suspendiert werden kann'; and further: 'Dazu gehört [...] eine prinzipiell unbegrenzte Befügnis, das heißt die Suspendierung der gesamten bestehenden Ordnung'. See Carl Schmitt, Politische Theologie: Vier Kapitel zur Lehre von der Souveränität (Berlin: Duncker und Humblot, 1996), 14, 18.

115 Schmitt, Politische Theologie, 18-9.

116 Schmoeckel, Humanität, 241, 280-1.

117 Schnapper, 'Les peines,' 94, 111.

118 Chiffoleau, 'Le crime,' 613. 
almost 'à tout le champ criminel'. ${ }^{119}$ This meant that in principle even petty crime, like theft, could be labelled as enormous or as a lesion of royal/divine majesty. Théry writes: 'L'histoire de l'énormité dévoile ainsi l'état permanent d'exception potentielle qui caractérisait le pénal d'Ancien Régime'. ${ }^{120}$ Agamben says: 'when the state of exception [...] becomes the rule, then the iuridico-political system transforms itself into a killing machine'. ${ }^{121}$ We do not suggest that the exception had become the rule, but rather that the ius commune does show a certain proclivity to transform itself, in response to particular threats, into Agamben's killing machine which we would propose to call sacrificial, to the extent that desacrificializing elements of due process are banned. What looms in the dark and hides behind the concept of crimen atrocius/enorme are the typical grotesque accusations of the most hideous crimes Girard has identified to be connected to scapegoat mechanisms. Crimes which were perceived to be extremely threatening since they attacked established taboos or the social, religious, and politico-theological distinctions. And Lacché has identified exactly these kinds of crimes to be at hand in the ordo non servatus. The crimen atrocius/enorme therefore now appears as an example of legal conceptualization of scapegoat dynamics, especially since the accused was considered to be a hostis omnium. The impression of being under severe threat fits moreover neatly into Schmitt's state of exception, as he writes: 'Der Ausnahmefall [...] kann höchstens als Fall aüßerster Not, Gefährdung der Existenz der Staates [...] bezeichnet [...] werden'. 'Im Ausnahmefall suspendiert der Staat das Recht, kraft eines selbsterhaltungsrechtes'. ${ }^{122}$ As virtually any defendant's alleged crime could be almost randomly labelled as atrocius/enorme to suspend procedural guarantees and as presumptions like mala fama counted as sufficient proof within the regime of the ordo non servatus, scapegoat dynamics got almost carte blanche, one could argue. On a purely conceptual level, we could say that contemporary due process as informed by the presumption of innocence is diagonally opposed to the ordo non servatus.

Let us now reconsider torture from a new perspective. So extensive was the body of rules restricting torture, that it was provocatively interpreted by Sbriccoli as a landmark in the development of procedural safeguards in favour of the defence. ${ }^{123}$ Pennington on the other hand remarks: 'Torture fundamentally undermines any idea of due process' ${ }^{124}$ This paradox should be interpreted in the light of the dialectic tension between rule and exception. In normal circumstances, violence is ruled by law. Law is overruled by violence, however, in response to heresy, witchcraft, and lese-majesty, threats so vicious they could dissolve the symbolic order. The legal order restraining violence then morphs into the anomic

119 Théry, 'Atrocitas/enormitas,' 31.

120 Théry, 'Atrocitas/enormitas,' 43 (Théry's italics).

121 Agamben, State, 86.

122 Schmitt, Politische Theologie, 13-4, 18-9.

123 Mario Sbriccoli, “Tormentum idest torquere mentem”: processo inquisitorio e interrogatorio per tortura nell' Italia communale,' in Storia del diritto penale e della giustizia: scritti editi e inediti (1972-2007), Tomo I (Milano: Giuffrè Editore, 2009), 126-8.

124 Pennington, The Prince, 157. 
violence of the state of exception. The force of law, once disembedded from the law, crushes its victims as fiercely and indiscriminately as Yahweh's wrath, one could say. ${ }^{125}$ For Schmitt, anomic violence is linked to the law by its suspension, ${ }^{126}$ 'includ[ing it] in the law through its very exclusion', as Agamben frames it. ${ }^{127}$ Girard also seems to know a version of anomic violence, namely the uncontained swift cataclysms of collective violence smashing arbitrary victims he considers as the secret heart of the sacred. Ritual sacrifice on the other hand operates at a slower pace as it is controlled and contained violence. It might be the predecessor of the law of criminal procedure exerting violence under the rule of law. ${ }^{128}$ Let us imagine a continuum reaching from Girard's anomic violence (the scapegoat mechanism), over Schmitt's anomic violence of the state of exception found

125 At this point in our account, we are able to argue for our use of Agamben's notion 'anomie'. It is an old debate whether the state of exception is to be situated within or without legal order. For the Middle Ages, says Agamben, a state of necessity or emergency was something external to law, which did not even suspend the law properly. At issue is not 'a status or situation of the juridical order as such [..;] rather, in each instance it is a question of a particular case in which the [...] law find $[\mathrm{s}]$ no application' (Agamben, State, 22-8, quote on 25). Being external to positive law does, however, not imply an exception to natural law, which dictates the preservation of the community. Exceptional measures taken in this respect could therefore still be regarded as 'légalité d'exception' (François Saint-Bonnet, L'État d'exception (Paris: Presses Universitaires de France, 2001), 124; Marc de Wilde, 'Emergency Powers and Constitutional Change in the Late Middle ages,' Tijdschrift voor rechtsgeschiedenis 83 (2015): 31; Thomas de Aquino, De regno ad regem Cypri, I, 9, II, 1, translated by Gerald B. Phelan, 〈http://dhspriory.org/thomas/DeRegno.htm\#1> (accessed 5 March 2016)). Agamben's claim that the medieval state of exception only concerns a particular case seems correct at first, as the criminal judge decides case by case whether to proceed within the ordo non servatus. Since, however, any crime could be labelled as atrocius/enorme, the penal system as a whole could, purely potentially and conceptually speaking, become a space of exception, and that is what Agamben's concept 'anomie' entails. If we interpret the ordo iuris as anti-sacrificial, a-nomie, defined as a 'zone of indifference' (Agamben, State, 23) has the advantage over 'légalité d'exception' to denote the threshold of legal and sacrificial order far better.

126 With regard to martial law for instance, Schmitt explicitly links the state of exception to violence (Carl Schmitt, Die Diktatur: Von den Anfängen des modernen Souveränitätsgedankens bis zum proletarischen Klassenkampf (Berlin: Duncker und Humblot, 1994), 168-73). This context is all the more relevant since Lacché draws just as much from martial as from criminal law when he expounds the ordo non servatus, sometimes described by the procedural formula 'ad modum belli' (Lacché, 'Ordo,' 365, 368).

127 Agamben, State, 54.

128 See note 39. 
in the ius commune's ordo non servatus ${ }^{129}$ (partially de-ritualized undue process meaning that procedure has become less complex and the violent response more immediate - likely culminating in a punishment tainted by sacrifice), to the ius commune's ordo iuris (partially desacrificialized due process possibly culminating in legal execution, a 'spectacle of suffering', ${ }^{130}$ whose sacrificial inheritance is still ready at hand) and ending in a contemporary conception of criminal procedure (more profoundly desacrificialized due process guided by the presumption of innocence and possibly culminating in a desacrificialized prison sentence $)^{131}$. When facing fundamental threats, the ius commune's ordo iuris withdraws by its partial suspension into the ordo non servatus: the Schmittian type of anomic violence it exerts can be labelled sacrificial and conceptually approaches the Girardian anomic violence of the scapegoat mechanism, so scapegoat dynamics become all the more legible. Sailing on quiet water, the ius commune operates under the ordo iuris and the violence it exerts conceptually already faintly approaches the desacr(ifici)alized order of modern due process. It is this coexistence of two modi operandi what makes the ius commune so confusing and interesting. Torture is at hand in both modi operandi but to a different degree. The seemingly unsurmountable contradiction between Sbriccoli's and Pennington's interpretation of torture reflects nothing else than two different fractions of a larger continuum wherein the penal law of the ius commune needs to be situated. Torture is, certainly in the ordo non servatus, the via dolorosa to Golgotha. But its embeddedness in the ordo iuris makes it at the same time, under the right conditions, an obstacle on the road to sacrifice (and these obstacles were serious enough, since judges are known to have been executed for not torturing by the book, and two thirds of the

129 We will offer some remarks, left for another occasion to be elaborated, concerning the question why Schmitt's theory, concerning only the post-Westphalian order, might be applied to the ius commune's penal system. Saint-Bonnet would probably advise against doing so. He argues that in the Middle Ages, the state of necessity had to be evident to all in order to justify exceptional action taken by the prince. This 'evidence' warrants against abuse and detaches the state of exception as far as possible from the decision of the monarch. The medieval state of exception's ultimate goal is to defend order where conventional means to do so fail (Saint-Bonnet, L'État, 140-4, 312-5). Schmitt's decisionism, implying that the sovereign is the one whom decides upon the exception (Schmitt, Politische Theologie, 14), seems out of reach indeed. Just as his sovereign dictator, suspending order to found a new one (Schmitt, Die Diktatur, 143-4). In the ius commune's criminal law, somewhat neglected by Saint-Bonnet, Schmitt's approach is, however, relevant. First, since the sovereign or the judge as his proxy decides upon the exception (whether the crime is atrocius/enorme and the ordo non servatus sets in). Secondly, because virtually any crime could be labelled as lese-majesty, transforming the accused in an enemy of order. Schmitt's friend-enemy distinction as the hallmark of the political (Carl Schmitt, The Concept of the Political, expanded edition, translation, introduction and notes by George Schwab e.a (Chicago-London: The University of Chicago Press, 1996), 27 and passim) is therefore at work in easily politicized criminal trials. Thirdly, since 'entre le XIIIe et le XVIIe siècle [une] contiguité essentielle [...] existe entre le procès et la politique, et plus spécifiquement encore entre le développement d'une forme de souveraineté et certains procès exceptionnels,' says Chiffoleau (Chiffoleau, 'Le crime,' 578). It might be the case, therefore, that Schmitt's early modern sovereignty has arisen as a new order out of the late medieval penal system's experiments with the state of exception.

130 This formula is taken from: Spierenburg, The Spectacle of Suffering.

131 We are merely referring to countries where the death sentenced has been abolished. The difficult American case is left unexplored here. 
accused put to the question by the Spanish Inquisition from 1570-1700 did not confess). ${ }^{132}$ Torture is therefore a true nexus between sacrifice and criminal law as governed by due process. Sacrificial and already to some extent anti-sacrificial, torture is exemplary for a fundamental ambivalence found throughout the ius commune's penal system, standing with one leg in the 'primitive' sacred, and with the other in a guilt-oriented criminal procedure informed by the presumption of innocence.

Another curious concept connected to the ordo non servatus is the canon law doctrine of the notorium. A notorium facti designates a fact known to all or at least the grand majority of the populace. It is distinguished from fama in the sense that the latter was mere suspicion and could be false, whereas the former was undoubtedly true because a crime was witnessed by many (ex multitudine praesentium) on clear daylight and could impossibly be denied. ${ }^{133}$ Invoking the notorium enabled the judge to bypass the ordo iuris: 'in notoriis iuris ordo est iuris ordinem non servare'. ${ }^{134}$ If the notoriety of the fact was established (not the fact itself), conviction followed without granting any rights of defence or further investigations. ${ }^{135}$ 'Sans hésitation, pas de droit', Latour said. ${ }^{136}$ And indeed, the doctrine of the notorium was already in the thirteenth century discredited since it trampled the sense of due process ${ }^{137}$ and some procedural guarantees were inserted. ${ }^{138}$ We are in dubio how to interpret this doctrine. On the one hand, one clearly perceives the dangers involved, and it was exactly to prevent abuse that it was reformed. We cannot help noticing a mob standing behind this institution, a mob absolutely certain of someone's guilt, so the presumption of innocence is out of the question. And the doctrine is mentioned in the context of heresy and apostasy. But the strict requirement that the multitude has seen $^{139}$ the crime taking place must count for something and does not warrant an interpretation too much in favour of scapegoat dynamics: we are unlikely dealing with an innocent defendant. The notorium facti, however, raised a little brother who was far more harmful: the notorium iuris, meaning that a court verdict, a fact proven in court or a confessed crime was imbued with the same degree of certainty as the notorium facti. ${ }^{140}$ On the notorium confessionis Schmoeckel writes: 'Weitere Verfahrensschnitte waren dann überflüssig, insbesondere war keine weitere Beweisaufnahme mehr nötig und ein Gegenbeweis war ausgeschlossen. Das Urteil konnte daher eigentlich umgehend

132 Schmoeckel, Humanität, 258, 265, 487.

133 Carlo Ghisalberti, 'La teoria del notorio nel diritto comune,' Annali di storia del diritto 1 (1957): 417-23.

134 Proposed translation: 'in notorious cases legal procedure consists in the non-observance of legal procedure'. See Ghisalberti, 'La teoria,' 445.

135 Fraher, 'The Theoretical,' 581.

136 Latour, Enquête, 367.

137 Schmoeckel, Humanität, 202.

138 Ghisalberti, 'La teoria,' 447.

139 We are far from doing justice to all the complexities of the notorium, because in some cases, a crime could be notorious ex auditu. See Ghisalberti, 'La teoria,' 425.

140 Ghisalberti, 'La teoria,' 427-32. 
ausgesprochen werden'. Also appeal was ruled out. ${ }^{141}$ The definitive value of (possibly tortured) confessions was granted by this notoriety. Interesting is the fact that the notorium iuris seems to receive its crushing force of law by mediation of the weight of the mob inserted in it via the notorium facti on which it was founded. It appears as if through notoriety one of the age-old pillars of law identified by Wesel shimmers through: group consensus. ${ }^{142}$ The doctrine of the notorium therefore conceptualizes the mob-dimension behind any exclusion penal law provides. ${ }^{143}$

\section{Poena extraordinaria}

Besides the poena ordinaria which was provided for by law, required full proof, and ordinarily meant the death penalty, the ius commune also knew, from the thirteenth century onwards, the milder poena extra-ordinaria, undetermined by law and left to the arbitrium iudicis. Langbein described it as 'punishment short of death for evidence short of full proof. ${ }^{144}$ The poena extraordinaria was imposed on the grounds of suspicion (Verdachtstrafe), rather than guilt, Schmoeckel explains. It could be inflicted when there was not enough circumstantial evidence to order torture or if a defendant had withstood the painful questioning without confessing. In theory, the latter should have been cleared from charges by passing the gruesome test. The poena extraordinaria, however, enabled the ius commune to react to suspicion when a public need for punishment was felt and the standard of proof was not met. ${ }^{145}$ Since the poena extraordinaria was neither in line with the law of proof nor with moral theology proclaiming unlawfully convicting innocents a mortal sin, the doctrine led a shadow existence in the margins, leading us back to the realm of exception. In practice, however, it was very often used. Jacques de Toureil (1656-1714) perceived the poena extraordinaria as "justice arbitraire' but still defended it as a sound way to prevent crime: 'ce plein pouvoir d'exercer les vengeances publiques tient davantage en bride les scelerats'. On the other hand, he also clearly perceived the poena extraordinaria's sacrificial potential, which is again intertwined with the reason of state, since he describes how the judges could become 'sacrificateurs', engaging in 'sacrifier [...] quelque particulier à la sureté publique'. The defendant is framed as 'l'innocent victime qu'ils immolent'. ${ }^{146}$ These are largely metaphors, since the poena extraordinaria was generally pecuniary or implied exile, and in early modern times, the galleys or forced labour. Death penalty and mutilation were excluded, expect in cases of crimina

141 Schmoeckel, Humanität, 204.

142 Wesel, Frühformen, 67.

143 One last remark on the ordo non servatus as a whole: we think that in as far the ordo non servatus was still considered an ordo, as Lacché has proposed, however, atrophied it may have been, Whitman's theory on procedure as providing moral comfort has not been refuted, although some qualifications would be welcome.

144 Langbein, Torture, 50.

145 Schmoeckel, Humanität, 295-300, 324, 340, 351-2.

146 Jacques de Toureil, 'Si le Juge peut imposer une demi-peine,' in Essais de Jurisprudence (Paris: J.B. Coignard, 1694), 315; also quoted by Schmoeckel, Humanität, 354, nn 381-2. 
atrocissima. ${ }^{147}$ These restrictions are in line with the 'taboo' on unwarranted bloodshed Whitman has delineated.

The roots of the poena extraordinaria, says Schmoeckel, are to be found in the 'war' waged against heresy from the twelfth century onwards. At first, proof of guilt was still required, but in 1179 , the Third Lateran Council declared that also those who merely helped heretics, by providing shelter or other support, suffered the same punishment as heretics. Soon also people who did not help, but whose orthodoxy was doubted, had to deliver an oath. Even if they succeeded, remnants of suspicion lingered: if a second time their true belief was questioned, they were considered relapsi. The church then handed them over to the secular authorities who punished them without any further scrutiny of the allegations. Only since Innocent III introduced the equivalence of heresy and lese-majesty, this meant the death penalty. Since 1215, failing to take the oath led to a year of excommunication, during which the suspect was expected to repent and confess to his errors. If he did not, he suffered the full force of the law. In case of heresy, mere suspicion therefore could lead to capital punishment. If someone was falsely accused of heresy, he found himself in a very awkward situation: or he abjured his alleged heterodoxy, thereby committing perjury which would be rewarded by eternal damnation, or he maintained his innocence and would be burned at the stake after a year of excommunication had passed. The church was perfectly aware of this catch 22 and offered martyrdom as compensation for its innocent victims. ${ }^{148}$

Again, we have acquainted ourselves with a doctrine conceptualizing an essential part of scapegoat dynamics: punishment for mere suspicion. ${ }^{149}$ The sacrificial logic at work in the poena extraordinaria was perceived by contemporaries and is corroborated by its origins in trials of heresy. Once more an institution tributary to scapegoat dynamics is completely in discord with the contemporary presumption of innocence. Although the mere name (extra-ordinaria) indicates affinity with the state of exception, it was a mainstream, but milder, punishment. Agamben's warning against conflation of rule and exception seems to the point in this regard, although moral theology's prohibition on unjustified bloodshed prevented this institution from degenerating into a true killing machine. To the extent the sacrificial thrust in medieval and early modern society was obstructed by the law of proof, it deviated and nested in shadow doctrines like these, which were less bloodstained but nevertheless operated in the spirit of the 'primitive' sacred. Differently put: to the extent that the impetus towards scapegoating was not served but impeded by torture legislation, it managed to find outlet valves like the poena extraordinaria. Following a by now familiar pattern, this normally milder doctrine

147 Schmoeckel, Humanität, 349-50.

148 Schmoeckel, Humanität, 300-22.

149 This aspect is related to the aleatory nature of scapegoat dynamics in the following way: in theory, anyone can accuse anybody of anything. If the community/authority sides with the accuser, and the accusation lacks substance or cannot be proven, someone gets punished for mere suspicion. As Douglas says with regard to a disaster for instance: 'someone already unpopular is going to be blamed for it' (Mary Douglas, Risk and Blame: Essays in Cultural Theory (LondonNew York: Routledge, 2003), 5). 
did, however, unleash its sacrificial devils in a substantially less restrained way in case of heresy. What could also be observed is that the martyrdom offered to the innocent victims of the inquisition is reminiscent of Girard's sacralization of the scapegoat.

\section{Absolutio ab instantia}

Instantia was the period in time, as Schmoeckel explains, during which a trial must be concluded and a verdict must be reached. Any acquittal was final since nobody had to stand trial twice for the same accusation (ne bis idem). If sufficient evidence for a poena ordinaria was lacking, and the judge was not satisfied with a poena extraordinaria, let alone an acquittal, he could order an absolutio ab instantia. This implied a temporary suspension of the procedure until new evidence had shown up which could warrant a poena ordinaria. The absolutio ab instantia formed the middle ground between a conviction and an acquittal and was another of the ius commune's ways to deal with suspicion. It could also be combined with a poena extraordinaria. The Malleus maleficarum (1478), an infamous guidebook on witch trials, summoned judges not to acquit but rather to use the absolutio ab instantia, because then future conviction remained possible. ${ }^{150}$ In early modern France, the absolutio ab instantia was especially well elaborated under the name "hors de cours'. The doctrine became so mainstream that French judges hardly ever acquitted anyone anymore. Hence, it does not surprise that Muyart de Vouglans (1713-1791) considers it as punishment: 'L'on peut dire en effet, qu[e c'est] la peine, non du crime, mais des présomptions \& des indices violens qui n'ont point été purgés,\& qui demandent une satisfaction particulière'. ${ }^{151}$ Extremely tantalizing is the fact that in France the absolutio ab instantia could be ordered indefinitely. In capital cases, this meant the accused faced, besides the obvious defamation involved, a life-long threat of possibly imminent death penalty, which would be executed if for instance a second witness came to the fore, when one had already testified during trial. ${ }^{152}$ Covarrubias (1512-1577) defended the absolutio $a b$ instantia by referring to the reason of state. ${ }^{153}$ Gomez (sixteenth century) did the same but preferred the poena extraordinaria to the absolutio ab instantia, because: 'si talis causa remaneret indecisa, reus accusatus, vel inquisitus remaneret in maximo damno, \& periculo, cum esset aperta via inimicis, \& sibi odiosis, ut possint quoti-

150 Heinrich Kramer, James Sprenger, Malleus Maleficarum, III, q. 20, see <www.malleusmaleficarum. org/downloads/MalleusAcrobat.pdf>, 511 (accessed 2 March 2015).

151 Muyart de Vouglans, Instituts au droit criminel ou Principes généraux sur ces matières, suivant le droit civil, al. Traité particulier des crimes (Paris: Le breton, 1757), VII, 1, 363.

152 Schmoeckel, Humanität, 360-1, 377, 382-6, 390.

153 Diego de Covarrubias, 'Variarum ex iure pontifico, regio et caesareo resolutionum libri III,' in Opera omnia (Augustae Taurinorum: apud Dominicum Tarinum, 1594), I, c.1 n.8. 
die super illo delicto inquietare \& molestare' ${ }^{154}$ Matthaeus (1601-1654) labelled the uncertainty provoked by the absolutio ab instantia 'durum et inhumanum'. ${ }^{155}$ Oldekop (1597-1667) saw in this doctrine the 'improbitas \& diabolica [...] malitia' of the courts. ${ }^{156}$ De Vouglans was in favour exactly because 'l'Accusé demeure toûjours incerti dubiique statûs'. ${ }^{157}$

The absolutio ab instantia prolongs the normative role of the defendant beyond the scope of the trial, possibly indefinitely. It reminds us of the fundamental importance why the different normative roles involved in the system of criminal justice should remain strictly limited in time. What seems to be at stake is a kind of pollution, in the archaic religious sense. Once polluted or stained by suspicion, one becomes impure, defamated. Those caught in the web of the absolutio ab instantia find themselves on the threshold of society's inside and outside, wandering in the no-man's land between guilt and innocence. Mary Douglas says: 'Persons in a marginal state [are] left out in the patterning of society [...] placeless [..,] their status is indefinable', ${ }^{158}$ an insight affiliated with de Vouglans' view on the matter. Moreover, since further proof to settle the matter is aspired, the absolutio ab instantia is a transitional state. Inspired by van Gennep, ${ }^{159}$ Douglas states that a person in transition 'is himself in danger and emanates danger to others' ${ }^{160}$ Although 'placeless', the victims of the absolutio ab instantia are already enough 'out of place' to be considered, like common convicts, as 'dirt', whereof Douglas writes: 'dirt is matter out of place [...] the by-product of a systematic ordering and classification of matter, in so far as ordering involves rejecting inappropriate elements'. ${ }^{161}$ The utterances of Gomez and de Vouglans indicate, we argue, that, because of the proposed archaic religious defilement involved, the defendant becomes extremely vulnerable for scapegoat dynamics (rumours and accusations) to be unleashed on his person. The civic trust protecting him from the criminal system is withdrawn, sometimes for life. The absolutio ab instantia is affiliated to

154 Proposed translation: 'if such a case would remain undecided, the defendant, who was accused or subjected to legal inquiry, would endure the greatest harm and danger, because the road would lay open for his enemies or those who bear him a grudge, so they could every day disturb and molest him by accusations concerning that crime'. See Antonio Gomez, Commentariorum variarumque resolutionum iuris civilis, communis, et regii tomi tres (Antverpiae: sumptibus P. et J. Belleri, 1615), 3, 13, n.28, 548; also quoted by Schmoeckel, Humanität, 382, n. 545; see Schmoeckel, Humanität, 382, n.544.

155 Antonius (II) Matthaeus, De criminibus ad lib. XLVII et XLVIII Dig. Commentarius (Vesaliae: typis ab Andreae ab Hoogenhuysen, 1672), D. 48,16 c.4, n.16, 722; also quoted by Schmoeckel, Humanität, 383.

156 Proposed translation: 'depravity and diabolical [...] maliciousness'. See Justus Oldekop, Observationes criminales practicae congestae (Bremae: Typis \& sumptibus Justi \& Jacobi Köhleros, 1654), tit.II, obs.8, n.14, 81; also quoted by Schmoeckel, Humanität, 383.

157 Proposed translation: 'the accused remains always of uncertain and doubtful repute'. See Muyart de Vouglans, Instituts, VII, 1, 363; also quoted by Schmoeckel, Humanität, 389, n. 596.

158 Mary Douglas, Purity and Danger: An Analysis of Concepts of Pollution and Taboo (London-New York: Routledge, 2002), 118.

159 Arnold van Gennep, The Rites of Passage (London-Henley: Routledge and Kegan Paul, 1977).

160 Douglas, Purity, 119.

161 Douglas, Purity, 44. 
scapegoat dynamics to the extent that it seems to create a reservoir of secondclass impure subjects henceforward easier disposable or 'sacrificable'. As punishment for suspicion, it bathes in a sacrificial atmosphere and tramples the presumption of innocence as we understand it today. At the same time, it serves as another outlet valve for scapegoat dynamics which cannot fully prosper within the legal order.

An epilogue on the importance of due process in the ius commune

Focusing mainly on the realm of exception might easily give the reader the wrong impression that the ius commune did not care much about procedural guarantees. Although some institutions, like the poena extraordinaria indicate a conflation of rule and exception, the ordo non servatus was not the standard. The ordo iuris has a significantly different story to tell and manifests serious commitment to due process. The ius commune's criminal law therefore abounds in equivocity and flexibility, torn and shifting as it was between rule and exception, between due process and scapegoat dynamics. This was observable especially in regard to torture legislation. But we must read this flexibility in the correct way and should refrain from taking it at face value as an argument that the ius commune just had not developed the adequate procedural protections to be able to prevent scapegoating. The mere fact they resorted to suspending the ordo iuris could even be interpreted as an indication it had (at least to some extent). We should not lose sight of the fact that the law of proof was in essence very demanding, aiming for nothing less than absolute certainty of guilt in a vain attempt to parallel the quality of God's judgement. When this ideal could not be reached, in theory, punishment was refrained from. The learned law refused for centuries in a row to back down from these theologically inspired sky-high aspirations, and although torture was a highly hypocritical way to live up to them - while serving the sociopolitical need for repression at the same time - the fact that the law of proof's core was not dismantled does indicate a serious concern for due process. Moreover, paradoxically, seeking refuge in the realm of exception testifies in its own way to the importance of law. Compared to an abolishment of procedural law's objectives, an option theologically unviable, a partial suspension of the law of proof yielded a crucial advantage, since it was a way to define 'a state of the law', as Agamben explains, 'in which the norm is merely not applied, but still remains in force. ${ }^{162}$

\section{Conclusion}

Using Girardian concepts as hermeneutical tools, we attempted to weave some shreds of what hopefully one day becomes a new web of meaning, wherein a number of aspects of criminal law could be coherently elucidated. Concatenating some of the legal concepts of the ius commune's criminal system we have explored, we arrive at a surprisingly complete conceptualization of scapegoat dynamics, going from the rumours and slander directed at outcasts on the verge of society (mala 
fama), over the grotesque accusations always directed at scapegoats (crimina atrociora/enormia), making them into hostes omnium, to ways of punishing the innocent (torture) or those merely deemed suspect (poena extrordinaria, absolutio ab instantia). Moreover, the pressing weight of the mob seems to have granted verdicts, proofs, and confessions to acquire full force of law (notorium iuris). Even tools to fill a reservoir of easily disposable defamated legal subjects are conceivable (absolutio ab instantia). The presumption of innocence that was used in the ius commune as a minor proof did not provide the defendant with fundamental protection but could sometimes even serve scapegoat dynamics, as it was readily retracted from people held in low esteem.

The sources we have quoted, especially on torture, but also on the poena extraordinaria and the absolutio ab instantia, prove that some contemporaries as well perceived a perverse logic at work in the ius commune, especially in those exceptional border zones where the ius commune is on the verge of dissolution. Torture, as the keystone of the inquisitorial trial, gave criminal procedure a strong aleatory and therefore sacrificial swing. Nevertheless, within the ordo iuris, its sacrificial potential was checked and balanced by restrictive regulations so extensive that some have read them as a landmark in the genesis of due process. When, however, the ordo iuris was suspended and the defendant (often a traditional scapegoat as a witch or a heretic) was tried in the ordo non servatus, we are facing a different situation: traditional limitations on torture and substantial procedural guarantees in favour of the defence were withdrawn. Drawing from Girard's idea that the legal guilt-oriented system is a rationalized superstructure erected on the foundations of the archaic randomizing sacrificial model, we have come to the following reading: in as far as the ordo iuris' law of proof had partially overcome scapegoat dynamics, the specific suspension of its most important procedural safeguards in the ordo non servatus opens up a realm of exception bringing about, instead of anarchic chaos, still an order, albeit of a not fully juridical, but rather sacrificial kind. What is unveiled when the legal order gets (partially) suspended, is its sacrificial infrastructure. The ordo non servatus' consanguinity to sacrificial order is readily discernible, since it provides a strongly aleatory and in fact relatively guiltindependent selection of a collective victim. But the realm of exception is not only found when procedure is suspended, it extends its tentacles to the realm of punishment as well, in the poena extraordinaria and the absolutio ab instantia. Albeit procedural law need not have been suspended here, material law was, since it did not allow the very thing these doctrines had to offer: punishment for mere suspicion. Because these aleatory forms of punishment, detached from the requirement of guilt, were anemic thanks to moral theology's interdiction of unwarranted bloodshed, they cannot fully be situated in sacrificial order, but they do attest to its logic.

What unifies all the legal concepts we have covered, is their being conceptually opposed to the modern account on the presumption of innocence as was presented by Duff. The accusatory force of mala fama permeated the whole of the inquisitorial trial. The judge acknowledging the mala fama investigated the matter to 
some extent under the presumption of guilt, although this by no means meant the burden of proof lay with the defence. Notorium facti was even tantamount to proof of guilt. The normative roles of defendant and offender completely merged, since defendants were punished without the standard of proof being met (torture, poena extraordinaria, absolutio ab instantia). Civic trust was not always reestablished if there was not sufficient proof of guilt (absolutio ab instantia). Due process as a whole was infringed upon in cases of crimina atrociora/enormia and the notorium facti. A pretty sound connection therefore can be established between scapegoat dynamics and the lack of the presumption of innocence as the structural principle of criminal procedure. If the presumption of innocence would have been established as it is today, the aforementioned legal concepts would to a large extent have become unthinkable. Refraining from any historical claims, we merely propose to consider the contemporary understanding of the presumption of innocence as a conceptual and institutionally anchored antidote for scapegoating tendencies within criminal law. ${ }^{163}$ If trespassing due process enhances legally codified scapegoat dynamics in creating an unwarranted opposition of all against one, '[n]est-ce pas', asks Latour, 'ce que le bon sens entend par "garantie juridique": que tous viennent au secours de chacun?'164

163 This is a purely theoretical and not an empirical claim. We have not investigated how much protection the presumption of innocence actually provides, nor do we claim that the presumption of innocence is in practice effective in eradicating scapegoat dynamics. The only claim we make is that, judging the theoretical framework of the contemporary law of proof, it comes across as the perfect conceptual filter to do so.

164 Latour, La fabrique, 276. 